\section{ALGEBRA THINKING PROCESS ON VOCATIONAL SCHOOL STUDENTS IN COMPLETING LINE PROBLEMS}

\author{
PROSES BERPIKIR ALJABAR PADA \\ SISWA SMK DALAM MENYELESAIKAN \\ PERMASALAHAN BARISAN
}

Jurnal Pendidikan Luar Sekolah

http://kolokium.ppj.unp.ac.id/ Jurusan Pendidikan Luar Sekolah

Fakultas Ilmu Pendidikan

Universitas Negeri Padang

Sumatera Barat, Indonesia

Volume 7, Nomor 2, Oktober 2019 DOI: $10.24036 /$ kolokium-pls.v7i2.350

\author{
Astutik Talun $\mathrm{Nu}^{1,2}$ \\ 1SMK Negeri 6 Malang \\ 2Email: astutiktalun@gmail.com
}

\begin{abstract}
This research is motivated by the observations of researchers when teaching, it was found that there are still many students who experience obstacles when solving row problems. This type of research is qualitative research with descriptive research type. The approach and type of study were chosen according to the researcher's goal which is to describe the students' algebraic thought processes in solving the problem of ranks. The findings in this study, namely high ability students can go through each stage of problem-solving as well as doing the algebraic thinking process well, while moderate and low ability students still often ignore the stage of looking back. They also still have difficulty doing the algebraic thought process. The algebraic thinking process of high-ability students is more complex than students of medium and low ability. Highly capable students experience the process of gathering ideas, clarifying ideas, evaluating ideas, and making decisions over and over again in the thought process he does in solving problems. Besides that, in the process of thinking, high-ability students also observe patterns, make generalizations, use meaningful symbols, use functions, and make mathematical models.
\end{abstract}

Keywords: Algebra Thinking, Vocational School, Line Problems

\begin{abstract}
ABSTRAK
Penelitian ini dilatarbelakangi oleh pengamatan peneliti ketika mengajar, ditemukan bahwa masih banyak siswa yang mengalami kendala ketika menyelesaikan permasalahan barisan. Jenis penelitian ini adalah penelitian kualitatif dengan jenis penelitian deskriptif. Pendekatan serta jenis penelitian tersebut dipilih sesuai tujuan peneliti yaitu untuk menggambarkan tentang proses berpikir aljabar siswa dalam menyelesaikan permasalahan barisan. Temuan dalam penelitian ini, yaitu siswa berkemampuan tinggi mampu melalui setiap tahapan penyelesaian masalah serta melakukan proses berpikir aljabar dengan baik, sedangkan siswa berkemampuan sedang dan rendah masih sering mengabaikan tahapan melihat kembali. Mereka juga masih mengalami kesulitan dalam melakukan proses berpikir aljabar. Proses berpikir aljabar siswa berkemampuan tinggi lebih kompleks dibandingkan siswa berkemampuan sedang dan rendah. Siswa berkemampuan tinggi mengalami proses pengumpulan ide-ide, pengklarifikasian ide-ide, penilaian ide-ide, dan pembuatan keputusan secara berulang-ulang dalam proses berpikir yang dilakukannya dalam menyelesaikan masalah. Selain itu pada proses berpikirnya
\end{abstract}


siswa berkemampuan tinggi juga melakukan pengamatan pola, membuat generalisasi, penggunaan simbol yang bermakna, penggunaan fungsi, serta membuat model matematika.

Kata Kunci: Berpikir Aljabar, SMK, Permasalahan Barisan

\section{PENDAHULUAN}

Materi barisan merupakan salah satu materi yang sangat penting untuk dipelajari siswa (Iryanti, 2004). Barisan sangat berkaitan dengan pengamatan pola. Dalam kehidupan sehari-hari banyak hal atau kejadian yang memiliki suatu pola. Oleh karena itu, banyak pula permasalahan dalam kehidupan sehari-hari yang memerlukan pengetahuan tentang materi barisan dalam menyelesaikannya. Namun, dari hasil pengamatan peneliti ketika mengajar, sejak tahun ajaran 2009/2010 sampai dengan 2012/2013 ditemukan bahwa masih banyak siswa yang mengalami kendala ketika menyelesaikan permasalahan barisan. Dari hasil wawancara dengan guru senior tempat peneliti mengajar, yakni di SMK, juga diperoleh informasi yang sama terkait hal tersebut. Contoh permasalahan yang muncul menurut guru senior tersebut antara lain tentang ketidakmampuan membedakan barisan bilangan aritmetika dan geometri, menentukan pola umum dari suatu barisan, dan menentukan suku ke- $n$ suatu barisan. Hal ini berarti, siswa belum memahami dengan baik konsep barisan bilangan. Selain itu beberapa siswa tidak mampu menyelesaikan permasalahan yang diberikan dengan alasan tidak hafal rumusnya. Kurangnya kemampuan dalam materi operasi aljabar yang berkaitan dengan proses menghitung dalam menyelesaikan permasalahan barisan juga menjadi kendala yang cukup berarti bagi siswa.

Penelitian tentang pembelajaran materi barisan antara lain oleh Ningrum \& Sutarni (2013); Nurdin (2015); dan Zaura \& Sulastri (2012). Berdasarkan penelitian yang telah dilakukan terhadap siswa tentang materi barisan terdapat beberapa permasalahan terkait kendala yang dialami siswa. Ningrum \& Sutarni (2013) menyatakan bahwa kendala yang dialami siswa antara lain pada aspek bahasa $(66 \%)$, aspek prasyarat $(56 \%)$, serta aspek terapan (58\%). Aspek bahasa yang dimaksud dalam penelitian tersebut adalah tentang pemahaman siswa pada masalah yang diberikan. Aspek prasyarat merupakan kemampuan menentukan hal yang ditanyakan dalam soal barisan. Sedangkan aspek terapan berkaitan dengan kesalahan penggunaan rumus atau prosedur serta kesalahan perhitungan.

Zaura \& Sulastri (2012) berpendapat bahwa dalam pembelajaran guru belum mampu mengajak siswa memahami konsep tentang barisan dengan baik sehingga siswa mengalami kendala ketika menggunakan rumus barisan untuk menyelesaikan permasalahan. Siswa juga tidak mengetahui hubungan antara materi barisan dengan materi fungsi akibat lemahnya penguasaan konsep mereka (Nurdin, 2015). Permasalahan atau kendala yang dialami siswa dalam menyelesaikan permasalahan barisan tersebut perlu untuk ditelusuri berdasarkan proses berpikir siswa.

Proses berpikir dapat ditelusuri sebagian dari pekerjaan siswa dalam menyelesaikan suatu permasalahan. Dari pekerjaan siswa tersebut akan terlihat indikasi bahwa siswa memahami secara baik konsep yang dibicarakan dengan memperhatikan bahwa keseluruhan proses penyelesaian yang dituliskan siswa adalah benar. Selain itu, indikasi bahwa siswa mengalami kesulitan atau ketidakmengertian konsep yang dibicarakan juga akan nampak 
dengan melihat adanya kesalahan. Seperti yang dikemukakan Nurul Z (2012) bahwa proses berpikir siswa dipengaruhi oleh pemahaman siswa terhadap permasalahan dan penguasaan konsep terkait masalah tersebut.

Melakukan analisis tentang proses berpikir siswa sangat penting untuk dilakukan karena dari kegiatan tersebut akan dapat diketahui apakah siswa telah menguasai konsep secara benar. Dalam setiap pembelajaran hendaknya guru juga menjadikan poin ini sebagai salah satu hal untuk diamati dalam diri siswanya. Seperti yang dikemukakan Hallagan (2006) bahwa guru harus peduli dengan proses berpikir siswa agar dapat melakukan koreksi serta mengembangkan kemampuan berpikir mereka. Selain itu, juga akan diketahui alasan-alasan siswa yang menyebabkannya mengalami kesulitan dalam menyelesaikan permasalahan dalam pembelajaran.

Penelitian tentang proses berpikir telah banyak dilakukan antara lain oleh Fardah (2012); Francisco \& Hahkioniemi (2006); Isoda (2012); Jazuli (2009); Patton (2012); dan Scusa (2008). Fokus yang diamati pada kajian tentang proses berpikir sangat beragam. Isoda (2012); dan Scusa (2008) menekankan kajiannya pada proses berpikir matematis. Fardah (2012); dan Jazuli (2009) berfokus pada proses berpikir kreatif sedangkan Francisco \& Hahkioniemi (2006); dan Patton (2012) mengkaji tentang proses berpikir aljabar.

Berpikir aljabar merupakan hal yang sangat penting dalam matematika (Ahuja, 1998; Windsor, 2010). Hal ini dapat dilihat dari temuan-temuan yang diperoleh dari kajian tentang berpikir aljabar oleh beberapa peneliti antara lain: Francisco \& Hahkioniemi (2006); Freiman \& Lee (2004); Hallagan (2006); Patton (2012); dan Windsor (2010). Menurut Hallagan (2006), proses berpikir aljabar penting untuk mengembangkan kemampuan berpikir siswa serta melakukan koreksi terhadap kesalahan yang dilakukan. Berpikir aljabar juga merupakan hal yang penting untuk mengembangkan konsep variabel dan fungsi (Freiman \& Lee, 2004). Mengajak siswa berpikir aljabar sejak awal akan dapat mengembangkan konsep yang baik tentang variabel sebelum mereka mempunyai banyak pengalaman dengan simbol-simbol.

Francisco \& Hahkioniemi (2006) menyatakan bahwa proses berpikir aljabar dengan pemberian masalah bersifat open ended terbukti dapat mengembangkan kemampuan siswa dalam melakukan penalaran ide-ide dan penyelesaian secara aljabar dengan lebih bermakna dan powerful. Berpikir secara aljabar juga akan meningkatkan kemampuan berpikir tidak hanya dalam aljabar tapi juga akan menjadikan sukses dalam penggunaan matematika (Windsor, 2010). Sedangkan Patton (2012) menyatakan bahwa penggunan model visual dan semi konkret dalam pengenalan berpikir aljabar di waktu dini dapat menciptakan link antara pengetahuan numerik dan konsep aljabar pada siswa.

Materi barisan bilangan berkaitan dengan pengamatan pola bilangan. Dalam penulisan bentuk umum pola barisan tersebut tentu melibatkan penggunaan simbol. Pada materi ini juga diperlukan kemampuan prasyarat tentang operasi hitung aljabar. Oleh karena itu untuk menelusuri proses berpikir siswa tentang permasalahan yang mereka alami terkait materi ini salah satunya dapat dilakukan dengan menganalisa proses berpikir aljabar mereka.

Berkaitan dengan permasalahan yang telah disebutkan sebelumnya, berpikir aljabar diperlukan dalam menyelesaikan permasalahan barisan. Seperti yang dikemukaan Freiman \& Lee (2004) bahwa berpikir aljabar adalah tentang berpikir untuk menggeneralisasi suatu bentuk atau pola. Berpikir aljabar terdiri dari bentuk-bentuk berbeda dalam berpikir dan pemahaman terhadap simbol (Van de Walle, 2003). Selain itu, menurut Freiman \& Lee (2004) berpikir aljabar juga dilakukan untuk mengembangkan konsep variabel dan fungsi. 
Materi barisan yang dihubungkan dengan konsep fungsi akan menjadikan pemahaman dalam benak siswa bahwa materi dalam matematika itu saling terhubung satu sama lain sehingga siswa dapat mengembangkan pengetahuan mereka.

Berdasarkan permasalahan yang telah dipaparkan tersebut serta kajian literatur yang dilakukan peneliti, penelitian tentang berpikir aljabar hanya dilakukan pada siswa tingkat Sekolah Dasar (SD) dan Sekolah Menengah Pertama (SMP). Peneliti belum menemukan penelitian terkait berpikir aljabar pada siswa tingkat Sekolah Menengah Kejuruan (SMK) yang setara dengan tingkat Sekolah Menegah Atas (SMA). Selain itu peneliti juga belum menemukan penelitian tentang berpikir aljabar pada materi barisan. Oleh karena itu, peneliti ingin melakukan penelitian berjudul "Proses Berpikir Aljabar Siswa SMK dalam Menyelesaikan Permasalahan Barisan" untuk memahami proses berpikir siswa ketika menyelesaikan permasalahan barisan.

\section{METODE}

Penelitian ini dilakukan dengan pendekatan penelitian kualitatif dengan jenis penelitian deskriptif. Pendekatan serta jenis penelitian tersebut dipilih sesuai tujuan peneliti yaitu untuk menggambarkan tentang proses berpikir aljabar siswa dalam menyelesaikan permasalahan barisan. Menurut Creswell (2009) dalam penelitian kualitatif, peneliti merupakan instrumen utama atau instrument kunci. Dalam penelitian ini, peneliti bertindak sebagai perencana, pelaksana, pengumpul data, penganalisis data penafsir data serta membuat laporan.

Proses berpikir aljabar siswa dalam menyelesaikan permasalahan barisan tersebut digali berdasarkan langkah penyelesaian masalah Polya. Langkah-langkah dibagi dalam empat langkah, yaitu pertama, memahami masalah. Informasi yang ingin digali pada langkah ini adalah proses berpikir aljabar siswa ketika pertama kali membaca permasalahan yang diberikan sampai pada tahap siswa mampu memahaminya. Peneliti mengeksplorasi informasi yang dipikirkan siswa pada selang waktu itu. Yakni tentang proses siswa mencari ide-ide, mengklarifikasi dan menilai ide-ide serta mengambil keputusan tentang pemahaman mereka terhadap permasalahan yang diberikan. Kedua, merencanakan penyelesaian. Pada langkah ini peneliti menggali proses berpikir aljabar siswa ketika telah memahami permasalahan yang diberikan sampai pada tahap siswa mampu merencanakan penyelesaian untuk masalah tersebut. Peneliti mengeksplorasi informasi tentang rencana penyelesaian yang dibuat oleh siswa. Peneliti meminta siswa mngemukakan gagasan atau ide mereka untuk menyelesaikan permasalahan yang diberikan sejak siswa mulai mengumpulkan ide-ide, mengklarifikasinya, dan menilainya serta membuat keputusan tentang rencana penyelesaian yang akan digunakan.

Ketiga, melaksanakan rencana penyelesaian. Peneliti mengeksplorasi informasi yang dipikirkan siswa pada saat melaksanakan rencana penyelesaian yang telah dibuat. Pada tahap ini peneliti menggali proses berpikir aljabar yang dilalui siswa dalam menyelesaikan permasalahan mulai dari proses mereka mengumpulkan, mengklarifikasi, dan menilai ide-ide serta membuat keputusan tantang penyelesaian yang dilakukan. Keempat, memeriksa kembali hasil penyelesaian. Pada langkah ini peneliti menggali proses berpikir aljabar siswa ketika telah melaksanakan rencana penyelesaian permasalahan yang dibuat sampai pada tahap siswa mampu memeriksa kembali hasil penyelesaian yang mereka kerjakan. Peneliti mengeksplorasi Proses mengumpulkan, mengklarifikasi, dan menilai ide-ide tentang memeriksa kembali 
penyelesaian yang telah mereka kerjakan serta membuat keputusan bahwa mereka telah yakin akan kebenaran penyelesaian tersebut.

Secara skematis langkah-langkah tersebut dapat digambarkan sebagai berikut.

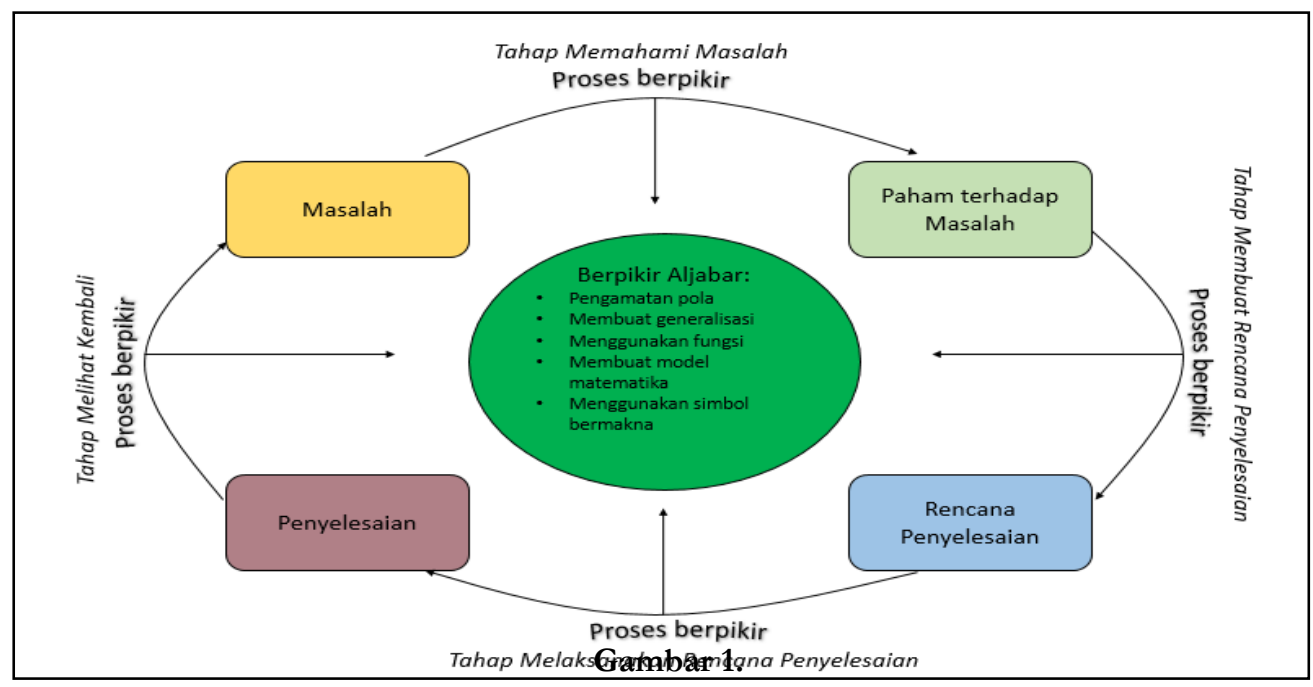

Diagram Alur Penelusuran Proses Berpikir Siswa

\section{HASIL PENELITIAN DAN PEMBAHASAN}

Tahapan penyelesaian masalah meliputi empat tahap yakni memahami masalah, menyusun rencana penyelesaian, melaksanakan rencana penyelesaian serta melihat kembali (Polya, 1971). Dalam setiap tahapan tersebut, siswa melalui proses berpikir. Proses berpikir tersebut meliputi proses pengumpulan ide-ide (generating ideas), pengklarifikasian ide-ide (clarifying ideas), penilaian ide-ide (assessing ideas), dan pengambilan keputusan (McGregor, 2007). Dalam melalui proses berpikir tersebut, siswa juga melalui proses berpikir aljabar. Proses berpikir aljabar tersebut meliputi pengamatan pada pola, generalisasi, penggunaan fungsi, penggunaan simbol secara bermakna serta membuat model matematika (Kaput, 1999).

Empat tahapan penyelesaian masalah tersebut tidak selalu dilalui secara keseluruhan oleh siswa. Dalam melakukan setiap tahapan penyelesaian masalah tersebut juga tidak selalu proses berpikir siswa terjadi secara runtut dan sempurna. Proses berpikir aljabar mereka pun juga beragam antara siswa satu siswa dengan siswa yang lain.

Seperti yang telah dijelaskan bahwa empat tahapan penyelesaian masalah tidak selalu dilalui secara keseluruhan oleh siswa. Hal tersebut terjadi terutama pada siswa dengan kemampuan matematika rendah dan sedang. Dalam melalui empat tahapan tersebut, mereka juga memiliki cara yang berbeda. Begitu pula dalam proses berpikir mereka. 


\section{Proses Berpikir Aljabar Siswa Berkemampuan Tinggi}

\section{Tahap Memahami Masalah}

Pada tahap memahami masalah, siswa berkemampuan tinggi melakukan proses mengumpulkan ide-ide (generating idea). Ia membaca soal dari awal untuk mengumpulkan informasi. Ia mengingat-ingat tentang konsep barisan aritmatika dan geometri yang telah dipelajarinya di kelas X. Ia melihat dan mengamati pola barisan gabungan yang diberikan. Ia mengamati tiap suku yang berdekatan maupun tidak.

Selanjutnya siswa melakukan proses pengklarifikasian ide (clariffing idea). Ia menemukan adanya pola pada suku-suku ganjil. Pola itu dikaitkannya dengan materi barisan dan deret yang telah dipelajarinya. Kemudian ia melakukan proses penilaian ide (assessing idea). Ia berhasil mengingat dan meyakinkan dirinya bahwa pola pada suku-suku ganjil yaitu "dikalikan tiga" merupakan ciri dari barisan geometri.

Proses pengklarifikasian ide (clarifying idea) ia lakukan kembali. Ia menemukan bahwa ada pola pada suku-suku genap. Kemudian siswa melalui proses penilaian ide (assessing idea) tersebut dan berhasil mengingat serta meyakinkan dirinya bahwa suku-suku genap yang memiliki ciri "ditambah tiga" merupakan suku-suku barisan aritmatika.

Akhir tahap ini, siswa berhasil membuat keputusan (complex thinking task) bahwa ia menemukan pola pada suku-suku genap merupakan pola barisan aritmatika dengan suku pertama 2 dan beda 3. Ia juga berhasil menemukan bahwa suku-suku ganjil merupakan pola barisan geometri dengan suku pertama 1 dan rasio 3. Ia juga memahami pertanyaan yang akan diselesaikannya yaitu mencari suku keseratus dari barisan gabungan itu yang ia terjemahkan dalam bahasa simbol yaitu $U_{100}$.

Berdasarkan penjelasan tersebut pada tahap memahami masalah ini ada proses berpikir aljabar yang dilakukan siswa yaitu: mengamati pola $\rightarrow$ melakukan generalisasi $\rightarrow$ mengamati pola $\rightarrow$ melakukan generalisasi $\rightarrow$ menggunakan simbol bermakna.

\section{Tahap Merencanakan Penyelesaian}

Dalam merencanakan penyelesaian, siswa berkemampuan tinggi kembali mengamati pola barisan yang ditemukan. Ia mengaitkan pertanyaan yang diberikan dengan pola itu. Ia mengaitkan pola barisan itu dengan bilangan 100 yang merupakan bilangan genap. Ini merupakan proses pengumpulan ide-ide (generating idea).

Selanjutnya, siswa melakuan proses pengklarifikasian ide-ide (clarifying ideas). Ia menemukan bahwa suku keseratus yang dicari merupakan suku genap dari barisan gabungan. Ia berpikir bahwa itu artinya suku keseratus merupakan suku dari barisan aritmatika.

Ia juga melakukan proses penilaian ide (assessing idea) yakni dengan berpikir bahwa karena barisan itu merupakan barisan gabungan, maka suku keseratus yang akan dicari merupakan suku kelima puluh dari barisan aritmatika yang ia temukan. Akhirnya, siswa membuat keputusan untuk mencari suku keseratus dari barisan gabungan itu dengan menggunakan rumus umum suku ke-n dari barisan aritmatika.

Ia kembali melakukan pengumpulan ide (generating ide) dengan mengingat-ingat rumus umum barisan aritmatika. Setelah berhasil mengingat dan menuliskannya di kertas jawaban, ia melakukan pengklarifikasian ide (clarfying idea) dengan mencoba menganalisa kebenaran rumus yang ditulisnya. Ia menerjemahkan simbol-simbol yang ia tulis. Lalu ia juga 
melakukan penilaian ide (assessing idea) tersebut berdasarkan analisanya pada rumus yang ia tulis dan membuat kesimpulan bahwa ia yakin bahwa rumus umum suku ke-n dari barisan aritmatika yang ia tulis adalah benar dan akan digunakannya untuk menyelesaikan soal.

Berdasarkan penjelasan tersebut pada tahap merencanakan penyelesaian ini ada proses berpikir aljabar yang dilakukan siswa yaitu: mengamati pola $\rightarrow$ melakukan generalisasi $\rightarrow$ menggunakan simbol bermakna $\rightarrow$ menggunakan fungsi.

\section{Tahap Melaksanakan Rencana Penyelesaian}

Dalam merencanakan penyelesaian, siswa berkemampuan tinggi mensubtitusi rumus umum suku ke-n dari barisan aritmatika yang telah ia tulis. Ia melihat simbol a, ia menerjemahkan sebagai suku pertama dari barisan aritmatika. Lalu ia melihat barisan aritmatika yang telah ditulisnya secara terpisah untuk mencari nilai suku pertama. Ia melakukan pengumpulan ide (generating idea). Selanjutnya ia menemukan suku pertama adalah 2. Kemudian dituliskannya pada lembar jawaban. Berarti ia memutuskan bahwa benar nilai a adalah 2. Ia melakukan hal yang sama untuk simbol $n$ dan b. Pada tahap memahami masalah ini ada proses berpikir aljabar yang dilakukan siswa yaitu: menggunakan fungsi $\rightarrow$ menggunakan simbol bermakna.

\section{Tahap Melihat Kembali}

Siswa berkemampuan tinggi mengumpulkan ide untuk melihat kembali hasil penyelesaiannya. Ia menuliskan dua macam simbol yaitu "_c dan " $\sqrt{ }$ " yang masing-masing menyatakan barisan geometri dan aritmatika. Kemudian ia menulis simbol itu sampai seratus simbol. Ia melihat simbol keseratus adalah " $\sqrt{ }$ ". Artinya, suku keseratus merupakan simbol dari barisan aritmatika. Ia melakukan pengklarifikasian ide (clarfying idea). Ia juga melakukan penilaian ide (assessing idea) dengan melihat simbol yang telah dituliskannya dan memutuskan bahwa bnar suku keseratus dari barisan gabungan itu merupakan suku kelima puluh dari barisan aritmatika. Berdasarkan penjelasan tersebut pada tahap melihat kembali ini ada proses berpikir aljabar yang dilakukan siswa yaitu: menggunakan simbol bermakna $\rightarrow$ mengamati pola $\rightarrow$ melakukan generalisasi.

\section{Proses Berpikir Aljabar Siswa Berkemampuan Sedang}

\section{Tahap Memahami Masalah}

Pada tahap memahami masalah, siswa berkemampuan sedang melakukan proses mengumpulkan ide-ide (generating idea). Ia membaca soal langsung pada barisan yang diberikan. Ia melihat dan mengamati pola barisan tersebut. Ia mengingat-ingat tentang konsep barisan dan deret yang telah dipelajarinya di kelas X. Ia mengingat percobaan menemukan barisan geometri dengan media kertas yang pernah dilakukannya. Ia mengamati tiap suku yang berdekatan maupun tidak.

Selanjutnya siswa melakukan proses pengklarifikasian ide (clarifying idea). Ia menemukan adanya pola pada suku-suku ganjil. Pola itu dikaitkannya dengan percobaan menemukan barisan geometri yang pernah dilakukannya. Kemudian ia melakukan proses penilaian ide (assessing idea). Ia berhasil mengingat dan meyakinkan dirinya bahwa pola pada suku-suku ganjil yaitu "dikalikan tiga" merupakan ciri dari barisan geometri.

Proses pengklarifikasian ide (clarifying idea) ia lakukan kembali. Ia mengamati pola barisan sisanya dan menemukan bahwa ada pola pada suku-suku genap. Kemudian siswa 
melalui proses penilaian ide (assessing idea) tersebut dan berhasil mengingat serta meyakinkan dirinya bahwa suku-suku genap yang memiliki ciri "ditambah tiga" merupakan suku-suku barisan aritmatika.

Akhir tahap ini, siswa berhasil membuat keputusan (complex thinking task) bahwa ia menemukan pola pada suku-suku genap merupakan pola barisan aritmatika dengan suku pertama 2 dan beda 3. Ia juga berhasil menemukan bahwa suku-suku ganjil merupakan pola barisan geometri dengan suku pertama 1 dan rasio 3. Ia juga memahami pertanyaan yang akan diselesaikannya yaitu mencari suku keseratus dari barisan gabungan itu yang ia terjemahkan dalam bahasa simbol yaitu $U_{100}$ dan ia tuliskan sebagai $U_{n}$ dalam lembar jawabannya.

Berdasarkan penjelasan tersebut pada tahap memahami masalah ini ada proses berpikir aljabar yang dilakukan siswa yaitu: mengamati pola $\rightarrow$ melakukan generalisasi $\rightarrow$ mengamati pola $\rightarrow$ melakukan generalisasi $\rightarrow$ menggunakan simbol bermakna.

\section{Tahap Merencanakan Penyelesaian}

Dalam merencanakan penyelesaian, siswa berkemampuan sedang kembali mengamati pola barisan yang ditemukan. Ia mengaitkan pertanyaan yang diberikan dengan pola itu. Ia mengaitkan pola barisan itu dengan bilangan 100 yang merupakan bilangan genap. Ini merupakan proses pengumpulan ide-ide (generating idea). Selanjutnya, siswa melakuan proses pengklarifikasian ide-ide (clarifjing ideas). Ia menemukan bahwa suku keseratus yang dicari merupakan suku genap dari barisan gabungan. Ia berpikir bahwa itu artinya suku keseratus merupakan suku dari barisan aritmatika.

Ia juga melakukan proses penilaian ide (assessing idea) yakni dengan berpikir bahwa karena barisan itu merupakan barisan gabungan, maka suku keseratus yang akan dicari merupakan suku kelima puluh dari barisan aritmatika yang ia temukan. Akhirnya, siswa membuat keputusan untuk mencari suku keseratus dari barisan gabungan itu dengan menggunakan rumus umum suku ke-n dari barisan aritmatika.

Ia kembali melakukan pengumpulan ide (generating ide) dengan mengingat-ingat rumus umum barisan aritmatika. Setelah berhasil mengingat dan menuliskannya di kertas jawaban, ia melakukan pengklarifikasian ide (clarfying idea) dengan mencoba menganalisa kebenaran rumus yang ditulisnya. Ia menerjemahkan simbol-simbol yang ia tulis. Lalu ia juga melakukan penilaian ide (assessing idea) tersebut berdasarkan analisanya pada rumus yang ia tulis dan membuat kesimpulan bahwa ia yakin bahwa rumus umum suku ke-n dari barisan aritmatika yang ia tulis adalah benar dan akan digunakannya untuk menyelesaikan soal.

Berdasarkan penjelasan tersebut pada tahap merencanakan penyelesaian ini ada proses berpikir aljabar yang dilakukan siswa yaitu: mengamati pola $\rightarrow$ melakukan generalisasi $\rightarrow$ menggunakan simbol bermakna $\rightarrow$ menggunakan fungsi.

\section{Tahap Melaksanakan Rencana Penyelesaian}

Dalam merencanakan penyelesaian, siswa berkemampuan sedang mensubtitusi rumus umum suku ke-n dari barisan aritmatika yang telah ia tulis. Ia melihat simbol a, ia menerjemahkan sebagai suku pertama dari barisan aritmatika. Lalu ia melihat barisan aritmatika yang telah ditulisnya secara terpisah untuk mencari nilai suku pertama. Ia melakukan pengumpulan ide (generating idea). Selanjutnya ia menemukan suku pertama adalah 2. Kemudian dituliskannya pada lembar jawaban. Berarti ia memutuskan bahwa benar nilai a 
Algebra Thinking Process on Vocational School Students in Completing Line Problems

adalah 2. Ia melakukan hal yang sama untuk simbol n dan b. Pada tahap memahami masalah ini ada proses berpikir aljabar yang dilakukan siswa yaitu: menggunakan fungsi $\rightarrow$ menggunakan simbol bermakna.

\section{Tahap Melihat Kembali}

Siswa berkemampuan sedang melewatkan tahapan ini ketika telah berhasil menyelesaikan soal yang diberikan. Maka pada saat itu tidak ada proses berpikir pada tahap ini.

\section{Proses Berpikir Aljabar Siswa Berkemampuan Rendah}

\section{Tahap Memahami Masalah}

Pada tahap memahami masalah, siswa berkemampuan rendah melakukan proses mengumpulkan ide-ide (generating idea). Ia membaca soal langsung pada pertanyaan yang diberikan. Ia menerjemahkan itu dalam simbol sebagai $U_{100}$ seperti yang ia tuliskan pada lembar jawaban. Ia mengingat-ingat tentang konsep barisan dan deret yang telah dipelajarinya di kelas X. Sepintas ia mengingat ada barisan aritmatika dan geometri. Tapi ia ragu tentang perbedaan keduanya. Ia juga mengingat adanya simbol-simbol yang biasa digunakan seperti a, $\mathrm{n}$, dan $\mathrm{r}$ namun ia tidak mengingat dengan pasti maknanya. Lalu ia melihat pada barisan bilangan yang diberikan. Ia mengamati pola barisan tersebut.

Selanjutnya siswa melakukan proses pengklarifikasian ide (clariffing idea). Ia menemukan adanya pola pada suku-suku ganjil. Pola itu dikaitkannya dengan materi barisan dan deret yang samar-samar diingatnya. Kemudian ia melakukan proses penilaian ide (assessing idea). Ia berhasil menemukan bahwa pola pada suku-suku ganjil yaitu "dikalikan tiga" merupakan ciri dari salah satu barisan yang pernah ia kenal. Namun ia tidak berhasil mengingatnya.

Proses pengklarifikasian ide (clarifying idea) ia lakukan kembali. Ia mengamati pola barisan sisanya dan menemukan bahwa ada pola pada suku-suku genap. Kemudian ia kembali mencoba melalui proses penilaian ide (assessing idea) dengan menemukan ciri "ditambah tiga" dari barisan itu. Namun, sekali lagi ia ragu dan tidak berhasil mengingat apakah itu barisan aritmatika atau geometri.

Akhir tahap ini, siswa berhasil membuat keputusan (complex thinking task) bahwa ia menemukan pola pada suku-suku genap memiliki pola "ditambah tiga". Ia juga berhasil menemukan bahwa suku-suku ganjil memiliki pola "dikalikan tiga". Ia juga memahami pertanyaan yang akan diselesaikannya yaitu mencari suku keseratus dari barisan gabungan itu yang ia terjemahkan dalam bahasa simbol yaitu $U_{100}$ dan ia tuliskan sebagai $U_{n}$ dalam lembar jawabannya.

Berdasarkan penjelasan tersebut pada tahap memahami masalah ini ada proses berpikir aljabar yang dilakukan siswa yaitu: mengamati pola $\rightarrow$ melakukan generalisasi $\rightarrow$ mengamati pola $\rightarrow$ melakukan generalisasi $\rightarrow$ menggunakan simbol bermakna.

\section{Tahap Merencanakan Penyelesaian}

Dalam merencanakan penyelesaian, siswa berkemampuan rendah kembali mengamati pola barisan yang ditemukan. Ia mengaitkan pertanyaan yang diberikan dengan pola itu. Ia mengaitkan pola barisan itu dengan bilangan 100 yang merupakan bilangan genap. Ini merupakan proses pengumpulan ide-ide (generating idea). Selanjutnya, siswa melakukan 
proses pengklarifikasian ide-ide (clarifying ideas). Ia menemukan bahwa suku keseratus yang dicari merupakan suku genap dari barisan gabungan. Itu berarti suku yang memiliki pola "ditambah tiga".

Selanjutnya, ia kembali melakukan pengumpulan ide (generating ide) dengan mengingat-ingat rumus-rumus pada materi barisan dan deret. Namun ia tidak berhasil melakukannya. Kemudian ia hanya berhasil mengingat rumus $\mathrm{Un}_{n}=\mathrm{ar}^{\mathrm{n}-1}$. Tapi ia tidak yakin dengan makna simbol-simbolnya. Lalu ia membuat keputusan untuk menuliskan rumus itu dan menggunakannya tanpa melalui proses pengklarifikasian dan penilaian ide tersebut.

Berdasarkan penjelasan tersebut pada tahap merencanakan penyelesaian ini ada proses berpikir aljabar yang dilakukan siswa yaitu: mengamati pola $\rightarrow$ melakukan generalisasi $\rightarrow$ menggunakan simbol bermakna (namun tidak dilakukan dengan baik)

\section{Tahap Melaksanakan Rencana Penyelesaian}

Dalam merencanakan penyelesaian, siswa berkemampuan rendah mensubtitusi rumus umum suku ke-n dari barisan geometri yang berhasil ia iangat tanpa tahu secara pasti itu rumus untuk barisan aritmatika atau geometri. Pada tahap ini siswa tidak melalui proses berpikir secara benar.

\section{Tahap Melihat Kembali}

Siswa berkemampuan rendah juga melewatkan tahapan melihat kembali ketika telah berhasil menyelesaikan soal yang diberikan. Maka pada saat itu tidak ada proses berpikir untuk tahapan melihat kembali ini.

\section{Pembahasan}

Penelitian ini menemukan bahwa siswa berkemampuan tinggi melewati keseluruhan dari tahapan penyelesaian masalah menurut Polya (1971) dalam menyelesaikan soal. Siswa berkemampuan sedang melewatkan tahapan melihat kembali baik dalam mengerjakan soal. Siswa berkemampuan rendah melewati tahapan penyelesaian masalah Polya secara keseluruhan dalam meyelesaikan soal.

Penelitian ini juga menemukan bahwa siswa berkemampuan tinggi juga melalui proses berpikir aljabar yang lebih kompleks dibandingkan siswa berkemampuan rendah dan sedang. Siswa berkemampuan sedang melalui proses berpikir aljabar yang lebih baik dibanding siswa berkemampuan rendah dalam menyelesaikan permasalahan. Namun, meskipun melakukan kesalahan dalam menyelesaikan soal, siswa berkemampuan rendah memiliki proses berpikir aljabar yang lebih baik dalam menyelesaikan permasalahan dibandingkan dengan siswa berkemampuan sedang.

Beberapa temuan dalam penelitian ini juga menguatkan penelitian yang telah ada sebelumnya. Temuan tersebut yakni tentang proses penggunaan simbol yang dilakukan siswa serta pengalaman belajar siswa dalam mengenal barisan dan deret yang dikaitkan dengan proses berpikir aljabar siswa.

Siswa berkemampuan rendah memiliki kelemahan dalam memahami barisan aritmatika dan geometri dan hanya terpaku pada rumus. Rumus itu pun tidak terlalu dihafal oleh siswa tersebut sehingga ia kesulitan dalam penerapannya juga dalam memaknai simbolsimbolnya. Akhirnya, siswa tersebut tidak dapat menyelesaikan soal dengan baik. Namun ketika dihadapkan pada soal kedua dengan perkenalan simbol-simbol yang diinformasikan 
pada soal, siswa berkemampuan rendah dapat bekerja dengan simbol-simbol itu secara baik. Oleh karena itu berpikir aljabar penting untuk mengembangkan kemampuan berpikir siswa serta melakukan koreksi terhadap kesalahan yang dilakukan (Hallagan, 2006).

Siswa berkemampuan sedang memiliki pemahaman lebih baik dalam mengenal barisan geometri dan aritmatika dibandingkan siswa berkemampuan rendah. Hal tersebut dapat terjadi karena siswa berkemampuan sedang memilki pengalaman belajar yang lebih baik terkait hal itu. Siswa berkemampuan sedang diperkenalkan tentang barisan geometri melalui percobaan sehelai kertas yang dipotong menjadi dua, kemudian masing-masing dipotong lagi menjadi dua, sehingga banyaknya kertas pada potongan pertama, kedua, dan seterusnya membentuk barisan geometri. Hal tersebut berbeda dengan siswa berkemampuan rendah yang menerima pembelajan tentang hal tersebut melalui rumus-rumus saja. Jadi penggunan model visual atau semi konkret dalam pengenalan berpikir aljabar di waktu dini dapat menciptakan link antara pengetahuan numerik dan konsep aljabar pada siswa (Patton, 2012).

\section{Kelemahan Penelitian dan Tindak Lanjut Penelitian}

Penelitian ini belum dapat menjelaskan perbedaan proses berpikir aljabar siswa berkemampuan rendah dan sedang secara jelas. Hal tersebut dapat terjadi akibat lemahnya prosedur dalam pemilihan subjek penelitian. Subjek penelitian dipilih dari kategori siswa berkemampuan matematika tinggi, sedang dan rendah yang didasarkan pada nilai raport matematika saja. Hak tersebut tidak terlalu menguatkan karena nilai raport telah melalui proses perumusan penilaian yang sedemikian rupa dan tidak mencerminkan tentang kemampuan aljabar siswa. Untuk itu diperlukan tindak lanjut pada penelitian selanjutnya yakni agar dilakukan tes yang memuat materi aljabar pada kegiatan prapenelitian untuk mengukur kemampuan siswa dalam aljabar.

Peneliti juga menyadari bahwa pada kegiatan wawancara terkadang masih tidak dapat mengontrol diri dalam mengajukan pertanyaan. Pertanyaan yang diajukan kadang masih muncul yang bersifat tidak eksploratif, sehingga siswa hanya menjawab "iya" saja. Oleh karena itu, tindak lanjut pada penelitian berikutnya adalah bahwa sebelum melakukan kegiatan wawancara perlu dilakukan latihan dalam mengajukan pertanyaan sesuai dengan pedoman wawancara yang dibuat. Penelitian ini juga masih terbatas pada proses berpikir aljabar siswa dalam menyelesaikan permasalahan barisan dan deret saja. Tindak lanjut pada penelitian berikutnya yakni perlu dilakukan penelitian tentang proses berpikir aljabar siswa untuk materi-materi yang lain.

\section{KESIMPULAN}

Siswa berkemampuan tinggi mampu melalui setiap tahapan penyelesaian masalah serta melakukan proses berpikir aljabar dengan baik. Sedangkan siswa berkemampuan sedang dan rendah masih sering mengabaikan tahapan melihat kembali. Mereka juga masih mengalami kesulitan dalam melakukan proses berpikir aljabar. Proses berpikir aljabar siswa berkemampuan tinggi lebih kompleks dibandingkan siswa berkemampuan sedang dan rendah. Siswa berkemampuan tinggi mengalami proses pengumpulan ide-ide, pengklarifikasian ide-ide, penilaian ide-ide, dan pembuatan keputusan secara berulang-ulang dalam proses berpikir yang dilakukannya dalam menyelesaikan masalah. Selain itu pada proses berpikirnya siswa berkemampuan tinggi juga melakukan pengamatan pola, membuat 
generalisasi, penggunaan simbol yang bermakna, penggunaan fungsi, serta membuat model matematika.

Siswa berkemampuan sedang dan rendah terkadang melakukan proses pengumpulan ide namun tanpa adanya proses pengklarifikasian dan penilaian ide-ide, mereka langsung melakukan pembuatan keputusan. Hal tersebut mengakibatkan penyelesaian yang mereka kerjakan masih mengalami kesalahan. Mereka juga masih mengalami kesulitan dalam melakukan pengamatan pola, membuat generalisasi, penggunaan simbol yang bermakna, penggunaan fungsi, serta membuat model matematika.

Penelitian ini juga menghasilkan beberapa temuan yang menguatkan penelitian sebelumnya, yaitu berpikir aljabar penting untuk mengembangkan kemampuan berpikir siswa serta melakukan koreksi terhadap kesalahan yang dilakukan. Selain itu, penggunaan model visual atau semi konkret dalam pengenalan berpikir aljabar di waktu dini dapat menciptakan link antara pengetahuan numerik dan konsep aljabar pada siswa.

Beberapa kelemahan penelitian ini yakni dilihat dari cara siswa menyelesaikan permasalahan sepertinya ada pengaruh dari gaya berpikir masing-masing siswa. Namun penelitian ini belum memperhatikan hal tersebut. Penelitian ini juga belum dapat menjelaskan perbedaan proses berpikir aljabar siswa berkemampuan rendah dan sedang secara jelas karena lemahnya prosedur dalam pemilihan subjek penelitian, yakni hanya didasarkan pada nilai rapor matematika saja. Selain itu, peneliti juga belum memiliki kemampuan bertanya secara baik dalam kegiatan wawancara.

\section{DAFTAR RUJUKAN}

Ahuja, O. P. (1998). Importance of Algebraic Thinking for Pre-service Primary Teachers. The Mathematics Educator, 3(1), 72-92.

Creswell, J. W. (2009). Research Design: Qualitative, Quantitative, and Mixed Methods Approach. California: SAGE Publications, Inc.

Fardah, D. K. (2012). Analisis Proses dan Kemampuan Berpikir Kreatif Siswa dalam Matematika Melalui Tugas Open-Ended. Kreano: Jurnal Matematika Kreatif-Inovatif, 3(2), 91-99. https://doi.org/10.15294/kreano.v3i2.2616

Francisco, J., \& Hahkioniemi, M. (2006). Insights Into Students' Algebraic Reasoning. In Proceedings of the 30th Conference of the International Group for the Psychology of Mathematics Education (Vol. 3, pp. 105-112). Prague. Retrieved from http:// users.jyu.fi/ mahahkio/PME30.pdf

Freiman, V., \& Lee, L. (2004). Tracking Primary Students' Understanding of the Equality Sign. In Proceedings of the 28th Conference of the International Group for the Psychology of Mathematics Education (Vol. 2, pp. 415-422). Bergen: Bergen University College. Retrieved from ftp://ftp.math.ethz.ch/EMIS/proceedings/PME28/RR/RR236_Freiman.pdf

Hallagan, J. E. (2006). The Case of Bruce: A Teacher's Model of his Students' Algebraic Thinking About Equivalent Expressions. Mathematics Education Research Journal, 18(1), 103-123. https://doi.org/10.1007/BF03217431

Iryanti, P. (2004). Strategi Pembelajaran Matematika SMA. Yogyakarta: Pusat Pengembangan Penataran Guru (PPPG) Matematika.

Isoda, M. (2012). Introductory Chapter: Problem Solving Approach to Develop Mathematical Thinking. Mathematical Thinking, 1(2012), 1-28. 
Algebra Thinking Process on Vocational School Students in Completing Line Problems

https://doi.org/10.1142/9789814350853_0001

Jazuli, A. (2009). Berpikir Kreatif dalam Kemampuan Komunikasi Matematika. In Prosiding Seminar Nasional Matematika dan Pendidikan Matematika (pp. 209-220). Yogyakarta:

UNY Press. Retrieved from https://eprints.uny.ac.id/7025/1/P11-Akhmad Jazuli.pdf

Kaput, J. J. (1999). Teaching and Learning a New Algebra with Understanding. In T. A. Romberg \& E. Fennema (Eds.), Mathematics Classrooms that Promote Understanding (pp. 133-155). London: Routledge. Retrieved from http://www.educ.fc.ul.pt/docentes/jponte/DA/DA-

TEXTOS/Kaput_99AlgUnd.pdf

McGregor, D. (2007). Developing Thinking; Developing Learning: A Guide to Thinking Skills in Education. Berkshire: Open University Press.

Ningrum, L. S., \& Sutarni, S. (2013). Analisis Kemampuan Siswa Menyelesaikan Soal Matematika dalam Bentuk Cerita Pokok Bahasan Barisan dan Deret pada Siswa Kelas XII SMA Al-Islam 3 Surakarta. In Seminar Nasional Pendidikan Matematika (pp. 110-117). Surakarta: Universitas Muhammadiyah Surakarta. Retrieved from https://publikasiilmiah.ums.ac.id/bitstream/handle/11617/3234/14_Analisis

Kemampuan Siswa Menyelesaikan Soal Matematika Dalam Bentuk Cerita Pokok Bahasan.pdf?sequence $=1$ \&is Allowed $=\mathrm{y}$

Nurdin, L. (2015). Analisa Pemahaman Siswa SMA Laboratorium Universitas Negeri Malang tentang Barisan dan Deret Berdasarkan Teori APOS. Universitas Negeri Malang.

Nurul Z, U. (2012). Analisis Proses Berpikir Siswa dalam Menyelesaikan Soal Cerita pada Pokok Bahasan Bangun Datar Segiempat Berdasarkan Tahapan Pemecahan Masalab Polya Siswa SMP Negeri 14 Surakarta Tahun Pelajaran 2011/2012. Universitas Sebelas Maret. Retrieved from https://digilib.uns.ac.id/dokumen/download/25035/NTMyNTU=/Analisisproses-berpikir-siswa-dalam-menyelesaikan-soal-cerita-pada-pokok-bahasan-bangundatar-segiempat-berdasarkan-tahapan-pemecahan-masalah-polya-siswa-SMP-Negeri14-Surakarta-tahun-pelajaran-20112012-abstrak.pdf

Patton, B. (2012). Analyzing Algebraic Thinking Using “Guess My Number" Problems. International Journal of Instruction, 5(1), 5-22. Retrieved from https:/ / files.eric.ed.gov/ fulltext/ED529112.pdf

Polya, G. (1971). How To Solve: A New Aspect of Mathematical Method. New Jersey: Princeton University Press.

Scusa, T. (2008). Five Processes of Mathematical Thinking (Summative Projects for MA Degree). Summative Projects for $M A$ Degree. Lincoln. Retrieved from http:/ / digitalcommons.unl.edu/cgi/viewcontent.cgi?article $=1030 \&$ context $=$ mathmi dsummative

Van de Walle, J. A. (2003). Elementary and Middle School Mathematics: Teaching Developmentally. (5, Ed.). Boston: Allyn \& Bacon.

Windsor, W. (2010). Algebraic Thinking: A Problem Solving Approach. Proceedings of the 33rd Annual Conference of the Mathematics Education Research Group of Australasia, 33, 665-672. Retrieved from https://researchrepository.griffith.edu.au/bitstream/handle/10072/36557/67823_1.pdf?sequence= 1\&isAllowed $=\mathrm{y}$

Zaura, B., \& Sulastri, S. (2012). Model Pembelajaran kooperatif Tipe STAD sebagai Upaya Meningkatkan Hasil Belajar Siswa pada Materi Barisan dan Deret Bilangan di Kelas IX SMP Negeri 1 Labuhanhaji Aceh Selatan. Jurnal Peluang, 1(1), 21-29. 